We wish to express our gratitude to Professor J. D. Boyd for his advice and encouragement. We would also like to thank Dr H.E. Daniels of the Statistical Laboratory, Cambridge, for the statistical analyses. Thanks are also due to Miss Ellington, Miss Dean and Miss Smith for technical assistance.

\title{
REFERENCES
}

de Schweinitz, G. E. \& Long, P. (1934). Arch. Ophthal., N.Y., Ir, 194.

Eveleth, D. F., Bolin, D. W. \& Goldsby, A. I. (1949). Amer. F. vet. Res, Io, 250.

Field, E. J. \& Brierley, J. B. (1948). F. Anat., Lond., 82, I 98.

Hume, E. M. \& Krebs, H. A. (1949). Spec. Rep. Ser. med. Res. Coun., Lond., no. 264.

Jeffers, W. A. \& Griffith, J. Q. Jr. (1942). In The Rat in Laboratory Investigation, ist ed., p. 192. [J.Q. Griffith, Jr., and E. J. Farris, editors.] Philadelphia: J. B. Lippincott Company.

Lamming, G. E., Woollam, D. H. M. \& Millen, J. W. (1954). Brit. F. Nutr. 8, 363 .

Mellanby, E. (1938-9). 7. Physiol. 94, 380.

Mellanby, E. (1944). Proc. Roy. Soc. B, 132, 28.

Millen, J. W., Woollam, D. H. M. \& Lamming, G. E. (1953). Lancet, 265, 1234.

Millen, J. W., Woollam, D. H. M. \& Lamming, G. E. (1954). Lancet, 267, 679.

Millen, J. W. \& Woollam, D. H. M. (1956). F. Neurol. Psychiat. 19, 17.

Moore, L. A. \& Sykes, J. F. (1940). Amer. F. Physiol. r3o, 684.

Moore, L. A. \& Sykes, J. F. (1941). Amer. F. Physiol. 134, 436.

Rigdon, R. H. (r952). Arch. Path. 53, 579.

Sorensen, D. K., Kowalczyk, D. M. \& Hentges, J. F. (1954). Amer. F. vet. Res. 15, $25^{8}$.

Warkany, J. (1947). Advanc. Pediat. 2, I.

Warkany, J. (1954). F. cell. comp. Physiol. (suppl.), 43, 207.

Wolbach, S. B. \& Hegsted, D. M. (1952). Arch. Path. 54, 13.

Woollam, D. H. M. (1952). Brain, 75, 259.

Woollam, D. H. M. \& Millen, J. W. (1953). Lancet, 264, 364 .

\section{The effects of chronic undernutrition and of total starvation on growing and adult rats}

\author{
By ELSIE M. WIDDOWSON AND R. A. McCANCE \\ Medical Research Council Department of Experimental Medicine, \\ University of Cambridge \\ (Received I2 fuly 1956)
}

People interested in human nutrition have always held that there was some inherent difference between the metabolism in, and the reactions of the body to, chronic undernutrition and complete deprivation of food. Their view is mainly based on the fact that oedema is a serious presenting problem in undernutrition, whereas it is said never to appear in people who are eating no food at all. There have been suggestions also from animal work that the effects on the weight and composition of the organs are different. Jackson ( $1915 a, b)$, for example, found that the liver of the adult rat lost less weight during chronic undernutrition than during acute starvation. A comprehensive review of the older work was made by Jackson (1925), and Keys and his collaborators (Keys, Brožek, Henschel, Mickelsen \& Taylor, 1950) have brought the subject up to date. 
There has been a lack of control about much of the work, and few investigators have studied the effects of undernutrition and starvation side by side. The experiments reported here were designed to make such a comparison.

\section{EXPERIMENTAL}

\section{Animals and experimental design}

Four groups of inbred black-and-white hooded rats of the Lister strain were used, consisting of adult males and females, with initial weights averaging $3 \mathrm{I} 4$ and $22 \mathrm{I} g$ respectively, and of rapidly growing male and female animals 4 weeks old, with initial weights that averaged 66 and $57 \mathrm{~g}$. Each of these groups was subdivided into three subgroups, a positive control group, a group to be starved and a group to be undernourished. Each subgroup contained six animals. 'The positive control subgroup and the subgroup to be starved were allowed, as previously, unlimited access to the stock diet, which consisted of bread, whole wheat, oat flakes, bran, wheat germ, yeast, milk, liver and greens. The animals in the subgroup to be undernourished were from that time given the stock diet, but in insufficient amounts to provide for their calorie requirements; they were kept in individual cages, so that each got its exact quota of food. The experiment was carried forward in this way for 5 weeks, and the degree of undernutrition was planned to bring the weights of the animals at the end of 6 weeks equal to what the subgroup to be starved was expected to reach at that time, i.e. after 5 weeks of full diet and 6 days with a free supply of water but total deprivation of food. The adults would have lived longer than 6 days without food, but there would have been a risk of losing the young animals; moreover, 6 days being the time used by Harrison (I953a), this allowed direct comparison to be made with her results. The positive control animals continued to have free access to the stock diet till they were killed, if adults, at the same time as those in the other subgroups, if young, 3 or 4 days before. The reason for doing so was that the weights of the adult positive controls were not changing towards the close of the experiment, whereas those of the young animals were still going up. A compromise thus became necessary; the reason for it-and indeed the whole design of the experiment-should be made clearer by reference to Fig. I. The design of the experiment made it possible to compare the effects of undernutrition with those of starvation in adult males, in adult females, in young males and in young females. It also, therefore, made it possible to compare the reactions of adult males to undernutrition and starvation with those of adult females or of young males and so on. Finally, it made it possible to compare the composition of the bodies of normal adult males with those of normal adult females or with those of normal young males or females. To have embarked upon all these comparisons would have made the presentation of the results most complicated or most tedious. Extensive simplification and selection from the findings have, therefore, been made, and only the outstanding ones will be given. 


\section{Sampling and analysis}

Each animal in turn was anaesthetized with Nembutal (Abbott Laboratories Ltd) and placed on a small weighed tray, the thorax was opened and about $\mathrm{I} \mathrm{ml}$. of blood was removed from the heart. The blood sample was used for the determination of haemoglobin in the whole blood and of chloride and pseudocholinesterase in the serum.

Next, the liver was rapidly removed and a piece weighing $0.3-0.5 \mathrm{~g}$ was snipped off, weighed and used for determination of glycogen. Another portion (about $0 \cdot 2 \mathrm{~g}$ ) was weighed into a small weighed tube and dried to constant weight at $100^{\circ}$. The remainder of the liver was then weighed, combined with the livers from the other five animals in the group, homogenized and sampled for further analysis. Duplicate samples were taken for nitrogen, phosphorus, chloride, fat and ash.

The kidneys, heart, spleen and adrenal glands of each animal were removed and weighed; these organs were not analysed separately, but were combined with the rest of the body, which was dried to constant weight at $100^{\circ}$, on the tray on which it was dissected, to reduce losses to a minimum. When the carcasses were dry, the one belonging to the rat whose weight at death had corresponded most exactly to the average weight of the group was analysed for chloride; the other five carcasses were put together in a large beaker, covered with conc. hydrochloric acid diluted $I: I$ and left to stand for some time. Further treatment followed the lines described by Venn, McCance \& Widdowson (1947). The dried carcass of the rat to be analysed for chloride was broken up into small pieces and divided among several $500 \mathrm{ml}$. conical flasks, so that each contained about $100 \mathrm{~g}$ or less of material. To each were added $50 \mathrm{ml}$. of $0.1 \mathrm{~N}-\mathrm{AgNO}_{3}$ and $50 \mathrm{ml}$. of conc. $\mathrm{HNO}_{3}$, and the flasks were heated in a boiling waterbath for about $6 \mathrm{~h}$, until all the tissue had disintegrated completely and the precipitated silver chloride had coagulated at the bottom of the flasks; the supernatant fluid was by that time clear. Solid ferric sulphate was added and dissolved in the solution, which was then left in the refrigerator to cool to $4^{\circ}$, and the excess $\mathrm{AgNO}_{3}$ was titrated against $0 \cdot 1 \mathrm{~N}-\mathrm{KCNS}$.

The chemical methods used for the analysis of the liver were those described by Harrison $(1953 b)$; those used for the analysis of the hydrochloric-acid digest of the whole bodies were those described by Spray \& Widdowson (I95I). Chloride in the serum was determined by the method of Sendroy (I937) and pseudocholinesterase by the method described by McArdle (I 940).

\section{RESULTS}

\section{Changes in weight}

Fig. I shows the mean weights of the twelve subgroups from the beginning to the end of the experiment. The points to note are (I) the success with which the weights of starved and undernourished animals were equalized, (2) the differences between the young animals and the adults, (3) the consequences of (r) and (2), namely, that to get the undernourished animals to the weights likely to be reached by those to be starved, 
it was necessary to let the undernourished young rats gain weight and the adult females stabilize their weights. Only the adult males could be allowed to lose weight consistently.
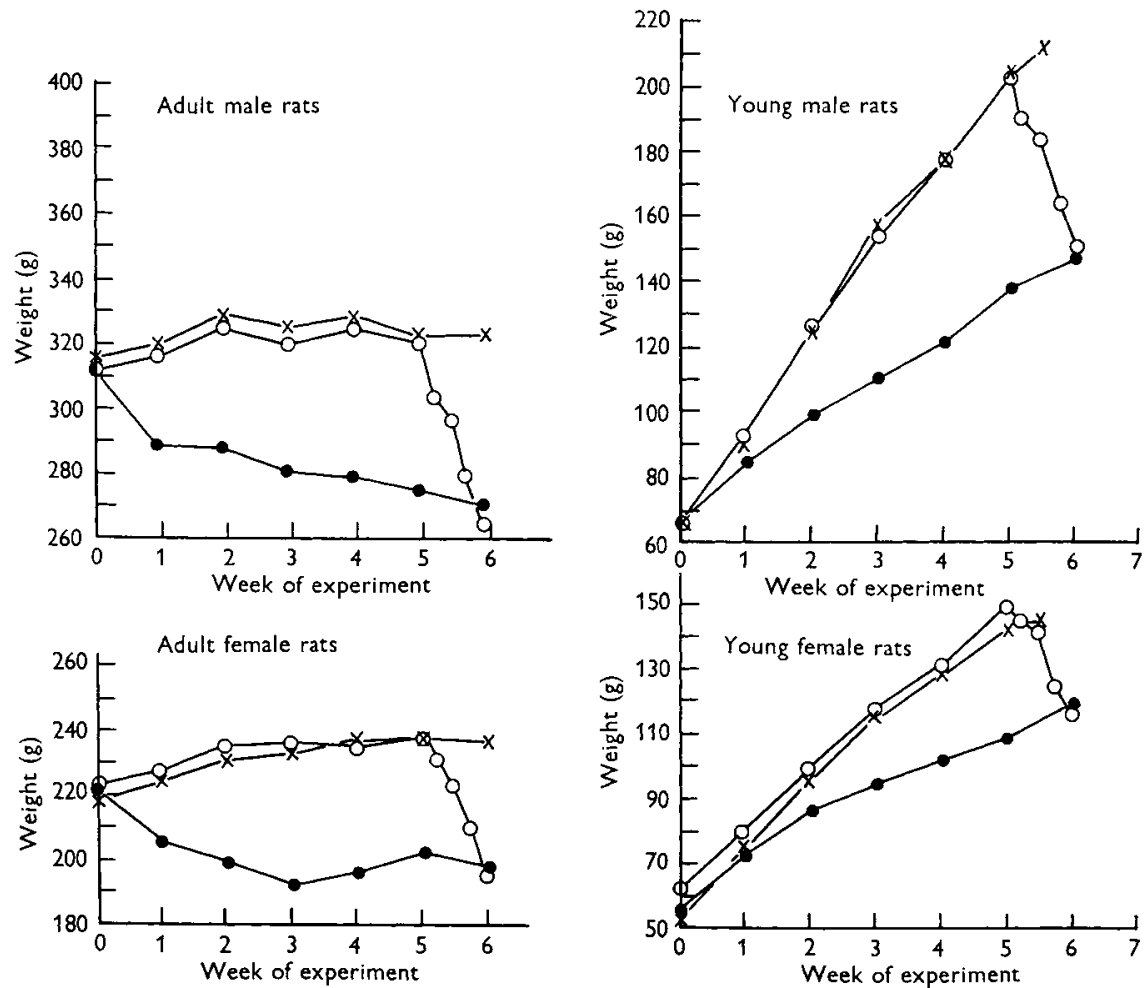

Fig. I. Mean body-weights of rats in the twelve experimental groups.

$x-x$, positive controls; $\bullet-\bullet$, undernourished; o-o, well nourished, then starved.

Table I. Mean composition of the bodies of the positive control rats

(Groups of six rats)

\begin{tabular}{|c|c|c|c|c|c|c|c|c|c|c|}
\hline $\begin{array}{l}\text { Type of } \\
\text { animal }\end{array}$ & $\begin{array}{l}\text { Body- } \\
\text { weight } \\
\text { (g) }\end{array}$ & $\begin{array}{c}\text { Water } \\
(\mathrm{g} / \\
\mathrm{r} 00 \mathrm{~g})\end{array}$ & $\begin{array}{c}\text { Fat } \\
(\mathrm{g} / \\
100 \mathrm{~g})\end{array}$ & $\begin{array}{c}\text { Protein } \\
(\mathrm{g} / \\
\mathrm{I} \circ \mathrm{g})\end{array}$ & $\begin{array}{c}\mathrm{Na} \\
(\mathrm{mg} / \\
\mathrm{IOOg})\end{array}$ & $\begin{array}{c}\mathrm{Cl} \\
(\mathrm{mg} / \\
\mathrm{I} 00 \mathrm{~g})\end{array}$ & $\begin{array}{c}\mathrm{K} \\
(\mathrm{mg} / \\
\mathrm{I} 00 \mathrm{~g})\end{array}$ & $\begin{array}{c}\mathrm{P} \\
(\mathrm{mg} / \\
\mathrm{I} 00 \mathrm{~g})\end{array}$ & $\begin{array}{c}\mathrm{Ca} \\
(\mathrm{mg} / \\
100 \mathrm{~g})\end{array}$ & $\begin{array}{c}\mathrm{Mg} \\
(\mathrm{mg} / \\
100 \mathrm{~g})\end{array}$ \\
\hline Adult: male & 315 & 59.5 & 16.8 & $22 \cdot 6$ & 122 & I 35 & 271 & 697 & I 195 & 52 \\
\hline female & 232 & $56 \cdot 3$ & $2 x \cdot 2$ & $19 \cdot 2$ & I I9 & I 3 I & 267 & 736 & I3I 5 & 49 \\
\hline $\begin{aligned} & \text { Young: male } \\
& \text { female }\end{aligned}$ & $\begin{array}{r}206 \\
142\end{array}$ & $\begin{array}{l}65.0 \\
64.0\end{array}$ & $\begin{array}{r}9.5 \\
11\end{array}$ & $\begin{array}{r}19.2 \\
19.8\end{array}$ & $\begin{array}{l}\text { I } 21 \\
\text { I } 8\end{array}$ & $\begin{array}{l}\text { I } 40 \\
\text { I } 41\end{array}$ & $\begin{array}{l}286 \\
284\end{array}$ & $\begin{array}{l}656 \\
690\end{array}$ & $\begin{array}{r}970 \\
1055\end{array}$ & 44 \\
\hline
\end{tabular}

\section{Composition of the bodies}

\section{Changes in the total constituents}

Table I shows the composition of the positive control animals, and Table 2 gives the changes, attributable to undernutrition and starvation, in the weights of the animals and in the total amounts of water, fat, protein and minerals within them. Values for males and females have been given separately and the value for the positive control animals has always been taken as roo. It will be seen that: $(a)$ the young 
animals lost proportionally more weight during starvation than the adults, which was perhaps to be expected. (b) The deprived animals, whatever their treatment, contained less of everything measured, including water, than the positive controls; in many instances chronic undernutrition produced almost the same effects as complete starvation after a full diet. (c) In particular, undernutrition differed little, if at all, from starvation in its effect on the amount of water and sodium in the body. There was certainly no great expansion in the volume of extracellular fluid in the body, which might have been the prelude to oedema in a human subject. The somewhat larger

Table 2. Mean relative reductions in body-weight and amounts of various constituents of the body caused by undernutrition and starvation, the corresponding amounts in the well-nourished control animals being taken as 100

\begin{tabular}{|c|c|c|c|c|c|c|c|c|c|c|}
\hline \multicolumn{11}{|c|}{ (Groups of six rats) } \\
\hline Adult: $\quad$ Type of animal & $\begin{array}{l}\text { Body- } \\
\text { weight }\end{array}$ & Water & Fat & Protein & $\mathrm{Na}$ & $\mathrm{Cl}$ & $\mathrm{K}$ & $\mathbf{P}$ & $\mathrm{Ca}$ & $\mathrm{Mg}$ \\
\hline $\begin{array}{l}\text { Male: undernourished } \\
\text { starved }\end{array}$ & $\begin{array}{l}84 \\
85\end{array}$ & $\begin{array}{l}88 \\
85\end{array}$ & $\begin{array}{l}69 \\
81\end{array}$ & $\begin{array}{l}80 \\
84\end{array}$ & $\begin{array}{l}89 \\
87\end{array}$ & $\begin{array}{l}92 \\
85\end{array}$ & $\begin{array}{l}82 \\
8 I\end{array}$ & $\begin{array}{l}93 \\
88\end{array}$ & $\begin{array}{l}93 \\
91\end{array}$ & $\begin{array}{l}77 \\
89\end{array}$ \\
\hline $\begin{array}{l}\text { Female: undernourished } \\
\text { starved }\end{array}$ & $\begin{array}{l}85 \\
84\end{array}$ & $\begin{array}{l}93 \\
90\end{array}$ & $\begin{array}{l}60 \\
63\end{array}$ & $\begin{array}{l}91 \\
92\end{array}$ & $\begin{array}{l}89 \\
88\end{array}$ & $\begin{array}{l}81 \\
82\end{array}$ & $\begin{array}{l}92 \\
79\end{array}$ & $\begin{array}{l}92 \\
91\end{array}$ & $\begin{array}{l}92 \\
92\end{array}$ & $\begin{array}{l}89 \\
85\end{array}$ \\
\hline $\begin{array}{l}\text { Young: } \\
\text { Male: undernourished } \\
\text { starved }\end{array}$ & $\begin{array}{l}70 \\
73\end{array}$ & $\begin{array}{l}71 \\
77\end{array}$ & $\begin{array}{l}66 \\
39\end{array}$ & $\begin{array}{l}72 \\
87\end{array}$ & $\begin{array}{l}68 \\
77\end{array}$ & $\begin{array}{l}70 \\
80\end{array}$ & $\begin{array}{l}68 \\
69\end{array}$ & $\begin{array}{l}71 \\
78\end{array}$ & $\begin{array}{l}73 \\
83\end{array}$ & $\begin{array}{l}61 \\
67\end{array}$ \\
\hline $\begin{array}{l}\text { Female: undernourished } \\
\text { starved }\end{array}$ & $\begin{array}{l}80 \\
78\end{array}$ & $\begin{array}{l}83 \\
83\end{array}$ & $\begin{array}{l}67 \\
47\end{array}$ & $\begin{array}{l}83 \\
90\end{array}$ & $\begin{array}{l}86 \\
84\end{array}$ & $\begin{array}{l}79 \\
82\end{array}$ & $\begin{array}{l}80 \\
78\end{array}$ & $\begin{array}{l}89 \\
94\end{array}$ & $\begin{array}{l}83 \\
94\end{array}$ & $\begin{array}{l}88 \\
86\end{array}$ \\
\hline
\end{tabular}

amount of water found in the undernourished adults than in the starved adults is to be correlated with the smaller amount of fat. $(d)$ In adults, undernutrition appeared to cause more loss of fat than starvation, whereas in the young animals it did the reverse. The result was the same in both sexes. With this finding must be coupled another, that the adult positive controls contained on average I $9 \%$ of fat and the young only $10.3 \%$ (Table $\mathbf{I}$ ). (e) Less protein was found in the bodies of the young animals after undernutrition than after starvation, but the effect was not so marked in adults. $(f)$ Both undernutrition and starvation materially reduced, and to about the same extent, the total amount of calcium and phosphorus in the bodies of the adults, but the reduction was less than that of the other constituents. Less calcium and phosphorus were found in the young animals after undernutrition than after full nutrition followed by starvation.

\section{Changes in the blood}

Table 3 gives the changes in certain of the constituents of the blood. Results for the chlorides and haemoglobin in males and females have been combined, those for pseudocholinesterase have necessarily been given separately, because of the large and well-known sex differences. The increase in the percentage of circulating haemoglobin during starvation is to be noted in both old and young animals, as is the low figure found in the young animals after undernutrition. Undernutrition appears to have raised the pseudocholinesterase in the males both old and young, although it certainly 
has not got this effect in man (Hutchinson, McCance \& Widdowson, 1951). As has been found by others (Harrison \& Brown, I95I), starvation materially reduced the pseudocholinesterase activity of female sera, and our results show that undernutrition had a similar effect. The pseudocholinesterase activity in the females was initially much higher than in the males, although the values in the young animals had not yet reached the adult levels.

\section{Table 3. Effects of undernutrition and of starvation on certain constituents of the blood}

(Groups of six rats)

\begin{tabular}{|c|c|c|c|c|}
\hline \multirow[b]{2}{*}{ Type of animal } & \multicolumn{2}{|c|}{ (Groups of six rats) } & \multicolumn{2}{|c|}{$\begin{array}{c}\text { Serum } \\
\text { pseudocholinesterase }\end{array}$} \\
\hline & $\begin{array}{c}\text { chloride } \\
\text { (M. and F.) } \\
\text { (m-equiv. } / \mathrm{l} . \text { ) }\end{array}$ & $\begin{array}{l}\text { Haemoglobin } \\
(\mathrm{M} . \text { and } \mathrm{F} .) \\
(\mathrm{g} / \mathrm{l} 00 \mathrm{ml} .)\end{array}$ & $\frac{\text { M. }}{\text { (units*/ml.) }}$ & (units*/ml.) \\
\hline $\begin{aligned} & \text { Adult: } \text { positive control } \\
& \text { undernourished } \\
& \text { starved }\end{aligned}$ & $\begin{array}{l}110 \\
109 \\
109\end{array}$ & $\begin{array}{l}\text { I } 5 \cdot 1 \\
\text { I } 5 \cdot 8 \\
\text { I } 6 \cdot 3\end{array}$ & $\begin{array}{l}6 \cdot 4 \\
8 \cdot 8 \\
6 \cdot 0\end{array}$ & $\begin{array}{l}29 \\
13 \\
15\end{array}$ \\
\hline $\begin{aligned} \text { Young: positive control } \\
\text { undernourished } \\
\text { starved }\end{aligned}$ & $\begin{array}{l}105 \\
108 \\
109\end{array}$ & $\begin{array}{l}14 \cdot 0 \\
12 \cdot 7 \\
15 \cdot 2\end{array}$ & $\begin{array}{l}6 \cdot 2 \\
9 \cdot 5 \\
7 \cdot 9\end{array}$ & $\begin{array}{l}19 \\
12 \\
14\end{array}$ \\
\hline
\end{tabular}

* A unit of pseudocholinesterase is the amount needed to liberate $\mathrm{r} \mu \mathrm{l} . \mathrm{CO}_{2} / \mathrm{min}$ from acetylcholine.

Table 4. Mean weights of organs as a percentage of mean body-weight

(Groups of six rats)

\begin{tabular}{|c|c|c|c|c|c|c|c|c|c|c|}
\hline \multirow{5}{*}{$\begin{array}{l}\text { Type of animal } \\
\text { dult: positive control } \\
\text { undernourished } \\
\text { starved }\end{array}$} & \multicolumn{2}{|c|}{$\overbrace{}^{\text {Liver }}$} & \multicolumn{2}{|c|}{$\overbrace{}^{\text {Spleen }}$} & \multicolumn{2}{|c|}{ Heart } & \multicolumn{2}{|c|}{ Kidneys } & \multicolumn{2}{|c|}{$\begin{array}{c}\begin{array}{c}\text { Adrenal } \\
\text { glands }\end{array} \\
\end{array}$} \\
\hline & M. & $\mathrm{F}$. & M. & F. & M. & $\mathrm{F}$. & M. & $\mathrm{F}$. & M. & F. \\
\hline & $2 \cdot 6$ & $2 \cdot 8$ & 0.27 & 0.24 & 0.31 & 0.38 & 0.65 & 0.67 & 0.014 & 0.032 \\
\hline & $2 \cdot 5$ & $2 \cdot 7$ & 0.28 & 0.27 & 0.32 & 0.37 & 0.63 & 0.70 & 0.018 & 0.030 \\
\hline & $2 \cdot 3$ & $2 \cdot 8$ & 0.24 & 0.28 & 0.34 & 0.38 & 0.67 & 0.72 & 0.018 & 0.031 \\
\hline Young: positive control & 3.9 & 4.0 & 0.58 & 0.76 & 0.38 & 0.45 & 0.77 & 0.81 & 0.018 & 0.034 \\
\hline undernourished & $3 \cdot 6$ & $3 \cdot 4$ & 0.54 & 0.54 & 0.42 & 0.43 & 0.79 & 0.80 & 0.024 & 0.033 \\
\hline starved & 2.9 & 4.0 & 0.36 & 0.50 & 0.44 & 0.47 & 0.77 & 0.88 & 0.029 & 0.050 \\
\hline
\end{tabular}

\section{Changes in the organs}

Organ weights as percentages of body-weight. Table 4 gives the mean weights, as a percentage of the body-weights, of certain of the organs of all the animals. The organs of both sexes were larger fractions of the body-weight when the animals were young. The liver tended to lose a greater percentage of its weight than the body did, the differences being statistically significant in the young and adult males after starvation (young males $t=10.4, P<0.01$; adult males $t=2.3, P=0.05$ ). The females behaved rather differently, for in both adult and young animals the liver formed exactly the same proportion of the body-weight in the starved animals as in the well-nourished controls. The adrenal glands accounted for a smaller percentage of the body-weight in 
the normal male than in the normal female, and the percentage increased in the males, particularly in the young animals, during undernutrition and starvation. The increase was not apparent in the females except in the young rats after starvation.

Table 5. Mean weight of the livers, percentage of water, fat, protein and glycogen in them, and pseudocholinesterase activity

\begin{tabular}{|c|c|c|c|c|c|c|}
\hline & & (Groups & f six rats) & & & \\
\hline Type of animal & $\begin{array}{l}\text { Weight } \\
\text { (g) }\end{array}$ & $\begin{array}{l}\text { Water } \\
(\mathrm{g} / \mathrm{I00} \mathrm{g})\end{array}$ & $\begin{array}{c}\text { Fat } \\
(\mathrm{g} / \mathrm{r} 00 \mathrm{~g})\end{array}$ & $\begin{array}{l}\text { Protein } \\
(\mathrm{g} / \mathrm{I} 00 \mathrm{~g})\end{array}$ & $\begin{array}{l}\text { Glycogen } \\
(\mathrm{g} / 100 \mathrm{~g})\end{array}$ & $\begin{array}{c}\text { Pseudo- } \\
\text { cholinesterase } \\
\text { (units*/ml.) }\end{array}$ \\
\hline Adult: & & & & & & \\
\hline Male: positive control & $8 \cdot 1$ & $69 \cdot 2$ & $5 \cdot 3$ & $22 \cdot 2$ & $1 \cdot 2$ & 44 \\
\hline undernourished & $6 \cdot 7$ & $69 \cdot 6$ & $4 \cdot 1$ & $2 \pi \cdot 5$ & $3 \cdot 2$ & 48 \\
\hline starved & $6 \cdot 0$ & $68 \cdot 1$ & 10.5 & $2 \times \cdot 0$ & 0.6 & 29 \\
\hline Female: positive control & $6 \cdot 5$ & $69 \cdot 3$ & $6 \cdot I$ & $2 \pi \cdot 4$ & 0.6 & 132 \\
\hline undernourished & $5 \cdot 3$ & $69 \cdot 6$ & 4.9 & $22 \cdot 6$ & $I \cdot I$ & 58 \\
\hline starved & $5 \cdot 5$ & $67 \cdot 1$ & $12 \cdot 3$ & $19 \cdot 3$ & 0.4 & 51 \\
\hline Young: & & & & & & \\
\hline Male: positive control & $8 \cdot 1$ & $70 \cdot 7$ & $4^{\circ} \cdot 0$ & $2 x \cdot 8$ & $2 \cdot 9$ & 30 \\
\hline undernourished & $5 \cdot I$ & $70 \cdot 1$ & $3 \cdot 9$ & $22 \cdot 7$ & 0.5 & 28 \\
\hline starved & $4 \cdot 3$ & $69 \cdot 9$ & $3 \cdot 8$ & $24 \cdot 0$ & $I \cdot I$ & 27 \\
\hline Female: positive control & $5 \cdot 6$ & $71 \cdot 3$ & 4.4 & $2 x \cdot 2$ & $\mathrm{I} \cdot 7$ & 72 \\
\hline undernourished & $3 \cdot 8$ & $69 \cdot 8$ & $4^{\cdot} \cdot 1$ & $22 \cdot 2$ & 0.6 & 45 \\
\hline starved & $4 \cdot 5$ & $69 \cdot 8$ & $4^{\circ} 9$ & $2 x \cdot 5$ & $\mathrm{I} \cdot 8$ & 33 \\
\hline
\end{tabular}

* A unit of pseudocholinesterase is the amount needed to liberate $\mathrm{I} \mu \mathrm{l} . \mathrm{CO}_{2} / \mathrm{min}$ from acetylcholine.

Table 6. Mean value for inorganic constituents of the liver

(Groups of six rats)

\begin{tabular}{|c|c|c|c|c|c|}
\hline Type of animal & $\begin{array}{c}\mathrm{Cl} \\
\text { (m-equiv./ } \\
\mathrm{kg})\end{array}$ & $\begin{array}{c}\mathrm{Na} \\
\text { (m-equiv./ } \\
\mathrm{kg})\end{array}$ & $\begin{array}{c}\mathrm{K} \\
\text { (m-equiv./ } \\
\mathrm{kg})\end{array}$ & $\begin{array}{l}\mathrm{Mg} \\
(\mathrm{mg} / \\
\mathrm{I} \circ \mathrm{g})\end{array}$ & $\begin{array}{c}\mathrm{P} \\
(\mathrm{mg} / \\
\mathrm{I} 00 \mathrm{~g})\end{array}$ \\
\hline $\begin{array}{l}\text { Adult: } \\
\text { Male: } \\
\begin{aligned} & \text { positive control } \\
& \text { undernourished } \\
& \text { starved }\end{aligned}\end{array}$ & $\begin{array}{l}24 \cdot 0 \\
26 \cdot 8 \\
25 \cdot 6\end{array}$ & $\begin{array}{l}26 \cdot 5 \\
29 \cdot 7 \\
27 \cdot 5\end{array}$ & $\begin{array}{l}77^{\circ} 4 \\
85^{\circ} \cdot 1 \\
75^{\circ} 9\end{array}$ & $\begin{array}{l}28 \cdot 1 \\
27 \cdot 5 \\
23 \cdot 2\end{array}$ & $\begin{array}{l}364 \\
343 \\
348\end{array}$ \\
\hline $\begin{aligned} \text { Female: } & \text { positive control } \\
& \text { undernourished } \\
& \text { starved }\end{aligned}$ & $\begin{array}{l}25 \cdot 1 \\
24 \cdot 8 \\
24 \cdot 8\end{array}$ & $\begin{array}{l}28 \cdot 0 \\
29 \cdot 9 \\
31 \cdot 7\end{array}$ & $\begin{array}{l}75 \cdot 7 \\
84 \cdot 9 \\
76 \cdot 7\end{array}$ & $\begin{array}{l}26 \cdot 9 \\
29 \cdot 5 \\
26 \cdot 9\end{array}$ & $\begin{array}{l}359 \\
371 \\
354\end{array}$ \\
\hline $\begin{array}{l}\text { Young: } \\
\text { Male: positive control } \\
\text { undernourished } \\
\text { starved }\end{array}$ & $\begin{array}{l}28 \cdot 5 \\
29 \cdot 3 \\
29 \cdot 3\end{array}$ & $\begin{array}{l}25 \cdot 4 \\
29 \cdot 7 \\
29 \cdot 6\end{array}$ & $\begin{array}{l}84 \cdot 0 \\
86 \cdot 5 \\
86 \cdot 2\end{array}$ & $\begin{array}{l}26 \cdot 7 \\
25 \cdot 7 \\
26 \cdot 9\end{array}$ & $\begin{array}{l}371 \\
383 \\
380\end{array}$ \\
\hline $\begin{aligned} \text { Female: } & \text { positive control } \\
& \text { undernourished } \\
& \text { starved }\end{aligned}$ & $\begin{array}{l}28 \cdot 2 \\
29 \cdot 3 \\
32 \cdot 4\end{array}$ & $\begin{array}{l}27 \cdot 4 \\
34 \cdot 7 \\
32 \cdot 9\end{array}$ & $\begin{array}{l}80 \cdot 3 \\
77 \cdot 6 \\
80 \cdot 1\end{array}$ & $\begin{array}{l}26 \cdot 3 \\
28 \cdot 0 \\
27 \cdot 2\end{array}$ & $\begin{array}{l}367 \\
368 \\
352\end{array}$ \\
\hline
\end{tabular}

Composition of the liver. Tables 5 and 6 show some of the organic and inorganic components of the liver for sexes and ages separately. The following will be noted: (I) The considerable increase in the percentage of fat in adult animals during starvation. The change was accompanied by compensatory ones in the opposite direction in the percentages of protein, glycogen and water, but no such change followed undernutrition in adults or either starvation or undernutrition in young animals. (2) The changes in glycogen were somewhat irregular, but the values were higher after under- 
nutrition than after starvation in the adult animals and the reverse was found in the young animals. (3) Both starvation and undernutrition reduced the amount of pseudocholinesterase in the female livers, but all the levels were lower in the immature animals. The changes in the male animals were much smaller, but there was a tendency at both ages and in both sexes for the activity to be slightly lower after starvation than after chronic undernutrition. The changes in enzyme activity did not correlate with alterations in the percentage of fat. (4) The decrease in total water during starvation in the adult animals was brought about by a fall in the cell water. The extracellular water, as measured by the chloride space, actually increased. The figures for cell water and extracellular water determined in this way are given in Table 7. The young animals' livers contained more extracellular and less intracellular water than those of the adults. The livers of the deprived animals always had more extracellular water in them than did those of the positive controls, but the effects of undernutrition were greater than those of starvation in the adults and less than those of starvation in the young. Starvation reduced the intracellular fluid more than undernutrition at both ages.

Table 7. Mean change in water compartments of the liver due to chronic undernutrition and to starvation

(Males and females together, groups of twelve rats)

$\begin{array}{ccc}\text { Type of animal } & \begin{array}{c}\text { Extracellular } \\ \text { fluid as } \\ \text { percentage of } \\ \text { liver weight }\end{array} & \begin{array}{c}\text { Intracellular } \\ \text { fluid as } \\ \text { percentage of } \\ \text { liver weight }\end{array} \\ \text { Adult: positive control } & \mathbf{2 2 \cdot 2} & 47 \cdot 0 \\ \text { undernourished } & 24^{\circ} \circ & 45^{\circ} 6 \\ \text { starved } & 23 \cdot 2 & 44 \cdot 3 \\ \text { Young: positive control } & 26 \cdot 8 & 44 \cdot 2 \\ \text { undernourished } & 27 \cdot 3 & 42 \cdot 6 \\ \text { starved } & 28 \cdot 3 & 4 I \cdot 6\end{array}$

(d) Total amount of nitrogen in the liver and the rest of the body. Table 8 shows how chronic undernutrition and starvation affected the total amount of nitrogen in the liver and in the rest of the body. The starved animals always lost a considerably greater proportion of the nitrogen from the liver than from the rest of the body, which is in conformity with the findings of Addis, Poo \& Lew (1936a,b). In chronic undernutrition there was not so much difference between the losses from the liver and the rest of the body. Starvation generally had a greater effect than undernutrition on the nitrogen in the liver, whereas the rest of the body was depleted of nitrogen more by chronic undernutrition than by starvation.

\section{DISCUSSION}

Weights of the bodies and of the total constituents in them

Reference to Fig. I shows that, whereas the adult animals, apart from the positive controls, all finished the experiment lighter than they were at the start, the young animals were considerably heavier at the close and consequently even the animals that had been undernourished for 6 weeks had been depositing materials within their bodies throughout that time. 
The changes in fat and protein (Table 2) may be explained as follows. During starvation the adult animal is known to lose fat and protein within well-defined ratios of each other (McCance \& Strangeways, I954). During undernutrition it may well be that the protein structure of the body is better maintained by the available food, and the fat of the body preferentially oxidized. One of the aspects of growth, however, has been found to be that during starvation young animals derive a smaller percentage of their energy requirements from protein than adults do (McCance \& Strangeways, 1954), which may explain why the loss of protein after starvation appeared to be smaller and the loss of fat larger than in adults. The young animals, although undernourished, were growing and gaining weight; hence, although they had not deposited as much fat as the positive controls, they had not deposited as much protein either, and the ratio of fat to protein in their bodies $(0.46)$ was almost exactly the same as in the positive controls $(0 \cdot 47)$.

Table 8. Mean relative reductions in total amount of nitrogen in the liver and in the rest of the body caused by undernutrition and starvation, the corresponding values for the positive control animals being taken as 100

$\begin{array}{lll}\text { (Groups of six rats) } & \overbrace{\text { Liver }}^{\text {Nitrogen }} & \begin{array}{c}\text { Rest of } \\ \text { body }\end{array} \\ \text { Type of animal } & & 79 \\ \text { Adult: } & 79 & 84 \\ \text { Male: undernourished } & 69 & 90 \\ \text { starved } & 86 & 92 \\ \text { Female: undernourished } & 77 & 72 \\ \text { starved } & 68 & 88 \\ \text { Young: } \begin{array}{l}\text { Male: undernourished } \\ \text { starved }\end{array} & 61 & 83 \\ \text { Female: undernourished } & 74 & 90\end{array}$

In the adults undernutrition and starvation both withdrew nearly as great a proportion of the calcium from the bones as they did of a number of the constituents from the soft tissues, which is perhaps surprising, but can be regarded as analogous to the opening stages of osteomalacia in undernourished human communities. The effect of starvation was even greater in the young animals. The smallness of the amounts of calcium found in the bodies of the young animals that had been undernourished must be explained by the fact that they had never grown as large as the animals that were well fed and subsequently starved, and their skeletons had always remained smaller.

\section{Blood and organs}

(I) The effect of starvation in increasing the concentration of haemoglobin in the circulating blood is probably attributable to a fall in the blood volume. The low figure in the young undernourished animals may perhaps be explained by absorption of less iron from a reduced intake. 
(2) In general the present results for starvation agree with those of Harrison (1953a) and of Harrison \& Brown (195r), but there have been some differences. Harrison ( $9533^{a}$ ), for example, found an increase in the percentage of fat only in the liver cells of females, but her rats were not as old as those used in our study and were in fact about intermediate in both age and size between our 'young' and 'adult' animals. The liver cells of her rats contained less fat initially. Harrison found that starvation for 6 days increased the percentage of protein in the liver cells of both male and female animals. In our experiments there was a fall in the percentage of protein in the liver of adults when starved, and a fall in the percentage of intracellular fluid. Age may have been responsible for the difference, for in the liver of the starved young animals the percentage of protein did increase. Harrison, moreover, found that the potassium and water in the cell fell pari passu: in our animals this relationship was not quite so close in the females.

\section{General}

The most interesting feature of these experiments seems to us undoubtedly to be the similarity between the effects of chronic undernutrition and of full nutrition followed by starvation. The response to the two procedures differed according to age and sometimes according to sex, as for pseudocholinesterase, but only rarely could undernutrition be said to have produced an effect demonstrably and clearly different from that of full nutrition followed by starvation. When it did, moreover, the reason was not always clear, nor did the effect recall experiences based on the study of man. Examples of chronic undernutrition producing effects unlike those of full nutrition followed by starvation were found in the relative reduction of nitrogen in the liver and in the rest of the body, in the deposition and loss of fat and calcium in young animals and in the concentration of haemoglobin in their circulating blood.

Differences between the individual animals, and the relatively small sizes of the groups, have created a certain amount of uncertainty when small changes only have been found, and the present experiments should be regarded as having been only a pilot survey. A number of the findings, if confirmed and explained by further experimental work, might have implications of considerable importance.

\section{SUMMARY}

I. Groups of six adult and young male and female rats were subjected to chronic undernutrition, or to full nutrition and then to starvation for 6 days, and killed when their weights were about the same (Fig. r). Their bodies, livers and blood were analysed, and the composition compared with that of the tissues of corresponding groups of animals which had been well-nourished throughout.

2. Undernutrition, and full nutrition followed by starvation, produced in general closely similar changes in the composition of the bodies and organs (Tables I-5), but age made a difference to the effects (Tables I-5), and so sometimes did sex (Tables 2-4).

3. The effects of chronic undernutrition differed from those of full nutrition followed by starvation in that $(a)$ the reduction in the amount of nitrogen was smaller in the livers of the undernourished animals, but greater in their bodies as a whole; 
(b) the bodies of the undernourished animals contained more fat, but less protein and calcium than those of the corresponding starved animals; $(c)$ the concentration of haemoglobin in the blood of the undernourished young rats was lower than in the blood of the corresponding starved animals; $(d)$ the livers of the adult undernourished animals contained much less fat, but more protein and glycogen than the livers of the adult starved animais.

\title{
REFERENCES
}

Addis, T., Poo, L. J. \& Lew, W. (1936a). F. biol. Chem. Ir5, I I I.

Addis, T., Poo, L. J. \& Lew, W. (1936b). F. biol. Chem. 115, I17.

Harrison, M. F. (1953a). Biochem. F. 55, 204.

Harrison, M. F. (1953b). Proc. Roy. Soc. B, 14I, 203.

Harrison, M. F. \& Brown, L. M. (195I). Biochem. F. 48, I 5 I.

Hutchinson, A. O., McCance, R. A. \& Widdowson, E. M. (195I). In Spec. Rep. Ser. med. Res. Coun., Lond., no. 275, p. 216.

Jackson, C. M. (1915a). Amer. F. Anat. 18, 75 .

Jackson, C. M. (1915b). F. exp. Zool. r9, 99.

Jackson, C. M. (1925). The Effects of Inanition and Malnutrition upon Growth and Structure. London: J. and A. Churchill.

Keys, A., Brožek, J., Henschel, A., Mickelsen, O. \& Taylor, H. L. (1950). The Biology of Human Starvation. Minneapolis: University of Minnesota Press.

McArdle, B. (1940). Quart. F. Med., N.S., 9, ro7.

McCance, R. A. \& Strangeways, W. M. B. (1954). Brit. F. Nutr. 8, 2 r.

Sendroy, J. (1937). F. biol. Chem. 120, 405.

Spray, C. M. \& Widdowson, E. M. (195I). Brit. F. Nutr. 4, 332.

Venn, J. A. J., McCance, R. A. \& Widdowson, E. M. (1947). F. comp. Path. 57, 314.

\section{Vitamin C economy of rabbits}

\author{
By LESLIE J. HARRIS, B. J. CONSTABLE, A. N. HOWARD \\ AND AUDREY LEADER \\ Dunn Nutritional Laboratory, University of Cambridge and \\ Medical Research Council
}

(Received 3I fuly I956)

The investigation to be described originated in the course of some studies on the relation between vitamin $\mathrm{C}$ and adrenal function, when it was found that the administration of ACTH or cortisone caused a massive enlargement of the liver in guineapigs and rabbits, but not in various other species examined, including rats, mice or chicks (Harris, Bland, Hughes \& Constable, I953). In searching for an explanation of this finding, the possibility had to be considered whether the special response of rabbits and guinea-pigs, as distinct from that of the other species, might conceivably be attributed to some common peculiarity in their vitamin $\mathrm{C}$ metabolism. This explanation seemed unlikely, for rabbits, in contrast with guinea-pigs, are not generally supposed to need vitamin C. Nevertheless, a study of the literature (see below) revealed the fact that past evidence about the vitamin $\mathrm{C}$ economy of rabbits was surprisingly conflicting. In these circumstances it was deemed desirable to make a direct test, in order to settle conclusively whether or not rabbits have in fact any need for vitamin $\mathrm{C}$ in their diet. 